\title{
The politics of the media: A cynical synopsis
}

\author{
STEVEN RATUVA
}

Australian National University

$\mathrm{M}$ EDIA BASHING' is not a professional hobby solely under the monopoly of disgruntled politicians. Paradoxically, it is also part of the culture of 'self-criticism' inherent in journalism itself, which journalists, from the time they are initiated into the newsroom, are professionally inculcated with. This nurtured critical media culture may manifest itself in the meticulous development and fine tuning of the art of denigrating other fellow journalists and rival media outlets and groups, if they are seen to pose a commercial, political or professional threat.

The power of the pen (or keyboard nowadays) can be used to inflame conflict, justify evil, create goodness, undermine political power, 'murder' characters, distort reality and invent truth. It can dazzle as well as numb; create as well as destroy; inform as well as misinform. Journalists compete to master these sets of social and moral dichotomies for diverse reasons: to please their bosses and thus ensure easy social mobility up the busy corporate ladder; make their stories marketable and generate public legitimacy; make a political point or two; or simply to 'survive'. This complex interplay of social and ethical dichotomies provide the basis for media politics and thus the environment within which journalists 'survive' and sometimes 'die'.

The media is not an autonomous, objective and innocent entity with a 'god's eye view' of the world. They do not always have the interest of humanity at heart. Rather, in many cases, it is a struggling human institution, driven and moulded by the need for economic survival, political patronage and public legitimacy. Journalists find themselves caught between these powerful political and eco- 
nomic imperatives and have to juggle, jinx, goose-step and wriggle their way through these to survive, let alone succeed, as journalists.

For economic survival, the media has to 'sell' itself using various techniques such as news sensationalism, advertisement, market competitiveness and business strategisation such as mergers and even monopoly. But how these are carried out may sometimes be ethically questionable.

While advertising may be commercially desirable, it has a less humane side to it. It's a form of psychological manipulation where pre-packaged contents and meanings are stuffed into people's minds destroying their sense of rationality to reason independently and sense of individual choice for what is 'good' or 'bad'. The epistemological reality presented is one-dimensional. Through professional manipulation, it deliberately fails to show the total picture of the product. This creates the so-called 'demand' for products, which economists rhetoricise about. Billions of dollars are spent every year by large corporations for this manipulative and conspiratorial purpose.

Thus one's 'choice' of Coca-Cola or Mcdonald's - which are potentially dangerous to one's health — is due in part to the intensive 'demand' creating brainwashing we all go through from morning to evening, seven days a week, through television, newspapers, radio etc. Today, advertising agencies are using highly sophisticated means, which play on human sentimental vulnerabilities to weaken people's 'guards'. Children are increasingly favourite targets. Sometimes sexuality and racism are used to sell products.

But of course, the media needs money to sustain itself and to pay journalists who have to pay the bills. This is the moral dilemma the media faces. It needs money yet it is actively part of the process of de-humanisation to survive.

The media has a fundamental role in intellectual reproduction in society. In other words, it helps to shape, pass on and facilitate ideas and views among people in a trans-cultural and sometimes trans-political way. But increasingly, this has been undermined by the media monopolies, which control television channels, newspapers and even radio stations. This has a number of effects. Firstly, it effectively diminishes people's choices in terms of what they receive; secondly, it leads to intellectual hegemony, where the media selectively determines what we should know and what we shouldn't know; thirdly, it helps to reinforce dominance of a particular political viewpoint representing political hegemony, especially in a world increasingly dominated by the US and its few allies.

One of the leading monopolists, Rupert Murdoch, goes around the world 178 PACIFIC JOURNALISM REVIEW 92003 
courting world leaders such as the Chinese premier, Italian PM and Tony Blair as a way of ensuring political endorsement of his media interests in those countries. His media empire was used to mobilise US and world opinion towards the Iraqi 'war of liberation'. The media in the US became the propaganda institutions for deception and lies about the Weapons of Mass Destruction and other myths. The frenzy of war-mongering by Bush was willingly taken up by the mainstream media and helped to ferment and inflame collective irrational hysteria and mob blood-lust, the ideological and moral cornerstones of American patriotism. 'Death to the enemies of America' became the daily sound byte dose to counter the 'Death to the infidels' trumpeting by equally hysterical antiAmerican Muslims. Anyone opposed to the killing of Iraqis was declared unAmerican, evil or insane.

Despite claims to objectivity, most mainstream media groups are politically aligned, either to political parties, governments or to some broad ideological position, around which they fashion their journalistic approach. This is very common not only in developing countries, also in Western liberal democracies.

In Britain for instance, among the main tabloids, the Daily Mirror is associated with center left politics and its scathing criticism of the dud monarch and right-wing Tories is normal journalistic practice. On the other side of the ideological continuum is the Daily Mail, which takes a very right-wing stance and is well known for its anti-immigrant and racist position and a benevolent love of conservative, upper crust English values. Its views sometimes border on neo-fascism.

In between the two tabloids are the News of the World and Sun, which thrive on political adventurism and opportunism. They shift their political orientation in relation to the shift in political tide. They were great supporters of the Conservatives when they were in power and suddenly became cheerleaders for Blair when he became prime minister. Such is the politically shifty and adventurist position of its owner, Murdoch.

The Times broadsheet (also owned by Murdoch) is an ideological cousin of the Daily Mail, with conservative pro-establishment views and a great disciple of corporate free enterprise morality. The main competitior of The Times is the center left and more intellectually inclined The Guardian, the darling of intellectuals, cultural analysts and progressive minds.

The United States media is by and large politically and intellectually narrow, compared to their British counterparts. It's a reflection of the ideologi- 
cal straight-jacket and political myopia of the 'American Way' and 'American Dream' thinking, where everything starts and ends in America. Television news and programmes for instance are exclusively American in focus and the rest of the world does not exist except if their half-literate president is visiting another part of the world which most Americans don't even know exists, or if their military heroes are out bombing and liberating a terrorist hideout in a far-away desert land.

Because of the significant Jewish ownership of some leading media outlets and strong Jewish political and corporate lobby power in the US, there is a strong pro-Israeli stance in relation to the current Middle-East conflict. The Palestinians arenormally portrayed as illegitimate squatters on the Israelis' 'god-given' land,and as terrorists and extremists.

The mainstream media in Australia and New Zealand, especially the widely circulated tabloids and broadsheets, do not really have any sharply distinctive ideological lines. They tend to oscillate between 'left' and 'right' politics. The Australian is an ideological mixture of The Times and The Guardian of Britain but there is still a predominance of right-wing views. Australian television stations are much more politically critical and 'progressive' than their US counterparts. The Government-owned Australian Broadcasting Corporation (ABC) has been labeled by John Howard supporters as 'left-wing', and in need of reform. The debate between pro-Bush/pro-Iraqi war 'right-wing' journalists and anti-Bush/anti-war 'left-wing' journalists has been raging in the television and print media in the last few months in an exciting way.

In Fiji, the media generally do not have any well-defined ideological positions, although there are usually accusations regarding the 'political bias' of certain reporters, editorials and media policies. In a way this is indicative of the general political climate, based largely, not on ideological differentiation but on politicisation of ethnicity. Generally, Indo-Fijian and indigenous Fijian journalists tend to have an inherent bias towards their own community. An 'objective' story often hides, usually not very well, the ethnic sympathy and slant of the journalists concerned. This was a dominant trend during the 2000 coup.

Journalists (just like academics) are among the most pretentious creatures - that's the nature of the beast, homo journaliticus. Objectivity and fair reporting are the ideological myths used to cover inherent political and ideological preference. They pretend to be objective and fair and use selected words to project this image. This is not new. In fact, humans are fundamentally political 
in nature (politics defined here broadly in relation to power relationships). Some journalists have come to the conclusion that one cannot be objective in the strict sense of the word and the issue is no longer objectivity but being 'right' or 'wrong'. What then is right and what then is wrong? For journalists, the answer to this question is not the conclusion to a debate but the very beginning of a long and endless squabble. After all journalism is politics by other means.

Dr Steven Ratuva, formerly of the University of the South Pacific, is a political sociologist at the Australian National University. This article was originally published in the Fiji Daily Post.

steven.ratuva@anu.edu.au 